\title{
Analisis Pengaruh Pengeluaran Pemerintah Sektor Pendidikan dan Sektor Kesehatan Terhadap Pertumbuhan Pendapatan Asli Daerah Serta Pertumbuhan Produk Domestik Bruto Sebagai Variabel Intervening (Studi Kasus Di Kota Mataram Nusa Tenggara Barat)
}

\author{
Hadi Mahmudi, Abdul Manan, Musta'in \\ Universitas Mataram
}

\begin{tabular}{l}
\hline A R T ICLE I N F O \\
\hline Keywords: \\
Government spending on \\
education and health, GDP \\
growth and PAD, Path \\
Analysis..
\end{tabular}

Received : 20 Des 2016; Accepted: 20 Februari 2017; Published: Maret 2017

ABSTRACT : This study aims to: examine the effect of Government Expenditures on education and health on the growth of Local Original Income in Mataram City through the growth of GRDP. This research uses quantitative approach with Path Analysis (Path Analysis) method. The data used is sourced from budget of 2008-2015 period at DinasPendidikan, Dinas Kesehatan and BPS of Mataram. The result of the research shows that 1 . The education sector government expenditure (X1) has a positive and significant effect on the growth of PAD and on the growth of GRDP (Y1) has positive but not significant influence. 2. Health sector government spending has a negative and insignificant effect on PAD growth and on GRDP growth (Y1) has 5.1.5. GDP growth (Y1) has a negative effect on PAD growth but is not significant. 3. Education sector government expenditure (X1) on indirect growth of PAD through GDP growth has negative and insignificant effect. 4. Health sector government expenditure (X2) on indirect growth of PAD through GDP growth has a positive and insignificant effect

Kata Kunci :

Pengeluaran pemerintah sector pendidikan dan kesehatan, Pertumbuhan PDRB dan PAD, Path Analysis.
ABSTRAK : Penelitian ini bertujuan untuk: mengkaji pengaruh Pengeluaran Pemerintah sektor pendidikan dan kesehatan terhadap pertumbuhan Pendapatan Asli Daerah di Kota Mataram melalui pertumbuhan PDRB. Penelitian ini menggunakan pendekatan kuantitatif dengan metode Analisa Jalur (Path Analysis). Data yang digunakan bersumber dari anggaran periode 2008-2015 pada DinasPendidikan, Dinas Kesehatan dan BPS Kota Mataram. Hasil penelitian menunjukkan bahwa 1.Pengeluaran pemerintah sektor pendidikan (X1) pengaruhnya positif dan signifikan terhadap pertumbuhan PAD dan terhadap pertumbuhan PDRB (Y1) memiliki pengaruh positif tetapi tidak signifikan. 2. Pengeluaran pemerintah sektor kesehatan pengaruhnya negatif dan tidak signifikan terhadap pertumbuhan PAD dan terhadap pertumbuhan PDRB (Y1) memiliki 5.1.5. Pertumbuhan PDRB (Y1) memiliki pengaruh negatif terhadap pertumbuhan PAD tetapi tidak signifikan. 3. Pengeluaran pemerintah sektor pendidikan (X1) terhadap pertumbuhan PAD secara tidak langsung melalui pertumbuhan PDRB memiliki pengaruh negatif dan tidak signifikan. 4. Pengeluaran pemerintah sektor kesehatan (X2) terhadap pertumbuhan PAD secara tidak langsung melalui pertumbuhan PDRB memiliki pengaruh positif dan tidak signifikan

Corresponding Author:

Alamat : Program Studi Ekonomi Pembangunan, Fakultas Ekonomi dan Bisnis, Universitas Mataram, Jln. Majapahit No. 62 Mataram.

e-mail:mahmudi@gmail.com 


\section{PENDAHULUAN}

\section{Latar Belakang}

Pendapatan Asli Daerah (PAD) merupakan tolok ukur yang penting untuk menentukan tingkat kemampuan daerah dalam melaksanakan otonomi daerah secara nyata dan bertanggungjawab. Otonomi daerah membawa dampak positif bagi daerah yang memiliki potensi sumber daya alam, tetapi tidak demikian dengan daerah yang miskin sumber daya alamnya, yang merupakan salah satu masalah yang dihadapi pemerintah daerah kabupaten/kota pada umumnya adalah terbatasnya dana yang berasal dari daerah sendiri (PAD), sehingga proses otonomi daerah belum bisa berjalan sebagaimana mestinya (Azis, 1997).

Menurut (sumitro,1995) Pembangunan pada dasarnya bertujuan untuk meningkatkan harkat, martabat, kualitas, serta kesejahteraan segenap lapisan masyarakat. Dalam kerangka itu pembangunan harus dipandang sebagai suatu rangkaian proses pertumbuhan yang berjalan secara berkesinambungan untuk mewujudkan tujuan-tujuannya.

Sejalan dengan hal tersebut maka keberhasilan pembangunan perkonomian dari suatu wilayah dan kinerjanya dapat diamati melalui beberapa indikator makro.Indikator makro tersebut dapat dianalisis melalui PDRB yang dapat didefinisikan sebagai penjumlahan nilai tambah bruto yang dihasilkan oleh seluruh unit kegiatan ekonomi yang beroperasi di wilayah/daerah tersebut dalam periode tertentu.Pertumbuhan ekonomi daerah berkaitan erat dengan peningkatan produksi barang dan jasa, yang diukur dengan besaran dalam Produk Domestik Regional Bruto (PDRB), dan juga sebagai indikator untuk mengetahui kondisi ekonomi suatu daerah dalam suatu periode tertentu.

Menurut Kuncoro (1995 : 334-358) Dalam penyelenggaraan otonomi daerah nantinya dikhawatirkan banyak daerah kabupaten/kota yang tidak mampu membiayai kebutuhan daerahnya. Hal ini dapat dilihat dari kondisi keuangan daerah yang ada selama ini di mana porsi antara PAD dengan bantuan pusat sangat menjolok sekali bahwa lebih separuh dari jumlah kabupaten/kota di Indonesia memiliki Pendapatan Asli Daerah (PAD) yang sangat minim dalam membelanjai kebutuhan anggaran daerahnya, yaitu di bawah $15 \%$ dari total anggaran secara keseluruhan.

Pengeluaran Pemerintah merupakan salah satu instrumen utama kebijakan dalam upaya peningkatan pelayanan umum dan kesejahteraan masyarakat di daerah. Oleh karena itu Pemerintah Daerah dan DPRD harus berupaya secara nyata dan terstruktur untuk menghasilkan APBD yang betul-betul mencerminkan kebutuhan riil masyarakat di daerah sesuai dengan potensi masing-masing. Untuk melihat apakah daerah telah siap secara finansial untuk menyongsong otonomi daerah, antara lain adalah dengan melihat apakah sumber-sumber penerimaan APBD nya mampu menutup anggaran belanja daerah yang bersangkutan. Di samping itu anggaran belanja pembangunan yang dialokasikan pada program proyek yang langsung menyentuh sektor ekonomi produktif masyarakat akan dapat meningkatkan perekonomian masyarakat (Uppal,1986)

Pendapatan Asli Daerah sangat penting dalam pelaksanaan pembangunan karena dana ini adalah milik pemerintah daerah sendiri sehingga pemerintah daerah mempunyai wewenang penuh untuk mengelola dana tersebut. Di lain pihak pemerintah daerah juga mempunyai tanggung jawab yang sangat besar terhadap pengelolaan keuangan yang berasal dari pendapatan asli daerah, karena dana itu berasal dari masyarakat daerah setempat yang berhak untuk mendapatkan kembali dana tersebut dalam bentuk pembangunan yang dilaksanakan di daerahnya.

Pertumbuhan APBD Kota Mataram yang cukup signifikan juga memacu pertumbuhan Pendapatan Asli Daerah, dimana tahun 2010 PAD Kota Mataram sebesar 44,49 miliar rupiah lebih naik menjadi 82,42 miliar rupiah pada tahun 2011. Pada tahun 2014 PAD Kota Mataram melonjak tajam mencapai 202,58 miliar rupiah lebih. Peningkatan realisasi penerimaan PAD yang telah dicsapai menunjukkan bahwa tingkat 
kemandirian daerah dalam melakukan pembiayaan pembangunan di Kota Mataram relatif baik.

Melihat pembangunan ekonomi Kota Mataram telah menunjukkan kemajuan yang cukup signifikan karena diimbangi dengan belanja modal daerah dalam meningkatkan infrastruktur dan prasarana yang masih kurang, tiap tahun pengeluaran pemerintah mengalami peningkatan dalam membangun sarana dan prasarana seperti pendidikan, kesehatan, pembangunan jalan tol, mall, sarana hiburan dan lain-lain sehingga mendorong investor dalam membangun usahanya di Kota Mataram.

Menurut(Mardiasmo,2004,)(Christiana, 2012), Optimalisasi penerimaan PAD harus didukung dengan upaya peningkatan kualitas layanan public yang dapat memberikan pelayanan bagi masyarakat di mulai dari pelayanan yang paling sederhana untuk menciptakan sumberdaya manusia yang berkualiatas yang memiliki peran yang sangat penting adalah kesehatan, pendidikan dan infrastruktur

Pertumbuhan ekonomi Kota Mataram tahun 2012 ditunjukan oleh laju pertumbuhan Produk Domestik Regional Bruto (PDRB) atas dasar harga konstan tahun 2000: naik dari tahun sebelunnya yaitu 3.02 persen (7,67: 2011). Pertumbuhan riil sektoral tahun 2012 mengalami fluktuasi dari tahun sebelunnya. Pertumbuhan tertinggi di capai oleh sector keuangan sebesar 13,97 persen, dengan peranannya terhadap PDRB 19,07 persen. Sektor pertambangan dan Pengangkutan dan Komunikasi mengalami penurunan paling tinggi yaitu minus 19,94 persen. Sektor Perdagangan dan Perhotelan adalah sector yang dominan memberikan sumbangan yang berati bagi perekonomian Mataram sebesar 23,27 dengan pertumbuhan riil sebesar 13,73 Persen. Sektor Industri pengolahan meskipun dengan penurunan sebesar 19,94 persen masih mempunyai peranan yang cukup besar terhadap pertumbuhan ekonomi, karena mampu memberikan andil sebesar 19,58 persen. Peningkatan pada masing-masing sector unggulan membawa dampak yang positif bagi perekonomian daerah terutama memberikan kontribusi besar terhadap Pendapatan Asli daerah (PAD). Besar kecilnya Pendapatan Asli Daerah (PAD) sangat dipengaruhi oleh tinggi pertumbuhan ekonomi daerah secara tegas tercermin di dalam Produk Domestik Regional Bruto (PDRB) dan dampak positif dari kebijakan proyek-proyek yang didanai atas prioritas dari Pemerintah Pusat yang selama ini diterima pemerintah daerah dan merupakan sumber pembiayaan terbesar bagi pemerintah daerah.

Terkait dengan pertumbuhan ekonomi Kota Mataram yang terus meningkat, hal ini tidak terlepas dengan kondisi sumber daya manusia yang dimiliki oleh Pemerintah Kota Mataram.Tingkat kualitas SDM di Kota Mataram. Periode Tahun 2010-2014 Indek Pembangunan Manusia Kota Mataram terus mengalami peningkatan pada tahun 2010 IPM nya sebesar 72,47 dan pada tahun 2014 meningkat menjadi 75,93. IPM Kota Mataram diatas rata-rata IPM Provinsi Nusa Tenggara Barat dan di atas rata-rata IPM nasional.

Berdasarkan uraian di atas terkait dengan faktor-faktor yang mempengaruhi PAD, maka Penulis tertarik untuk meneliti PAD Kota Mataram dan menuangkan hasilnya dalam karya ilmiah berjudul "Analisis Pengaruh Pengeluaran Pemerintah Sektor Pendidikan dan Sektor Kesehatan Terhadap Pertumbuhan Pendapatan Asli Daerah Serta Pertumbuhan Produk Domestik Bruto Sebagai Variabel Intervening

\section{Perumusan Masalah}

Berdasarkan uraian yang telah dikemukakan sebelumnya, maka yang menjadi rumusan masalah dalam penulisan ini adalah: Apakah Pengeluaran Pemerintah sektorpendidkan dan kesehatan melaluiPertumbuhan Produk Domestik Regional Bruto berpengaruh secara signifikan terhadap pertumbuhan Pendapatan Asli Daerah di Kota Mataram? 


\section{Tujuan Penelitian}

Dalam penulisan ini tujuan yang ingin dicapai penulis adalah: Untuk mengkaji pengaruh Pengeluaran Pemerintah sektor pendidikan dan kesehatan terhadappertumbuhan Pendapatan Asli Daerah di Kota Mataram melalui pertumbuhan PDRB

\section{Manfaat Penelitian}

Adapun manfaat penulisan ini adalah:

1. Sebagai input bagi pemerintah daerah serta yang terlibat langsung dalam pengelolaan Pendapatan Asli Daerah (PAD) di Kota Mataram.

2. Untuk memberikan sumbangan pemikiran dan memperkaya khasanah penelitian tentang Pendapatan Asli Daerah (PAD) khususnya di Kota Mataram

\section{TINJAUAN PUSTAKA}

\begin{abstract}
Konsep Pendapatan Asli Daerah
Pendapatan Asli Daerah (PAD) berdasarkan pasal 157 huruf a UndangUndang Nomor 32 Tahun 2004 tentang Pemerintahan Daerah mengisyaratkan bahwa pemerintah daerah dalam mengurus rumah tangganya sendiri perlu diberikan sumber-sumber pendapatan atau penerimaan keuangan daerah untuk membiayaai seluruh aktifitas dalam rangka pelaksanaan tugas-tugas pemerintahan dan pembangunan untuk kesejahteraan masyarakat secara adil dan merata, komponen tersebut berasal hasil pajak daerah, hasil retribusi daerah, hasil pengelolaan kekayaan daerah yang dipisahkan dan Lain-lain PAD yang sah. Keempat komponen PAD tersebut juga merupakan sumber-sumber keuangan daerah, oleh karena itu, Pendapatan Asli Daerah merupakan salah satu komponen sumber keuangan daerah.Sumber-sumber PAD merupakan bagian keuangan daerah yang dipungut berdasarkan undangundang dan peraturan yang berlaku di daerah tersebut.
\end{abstract}

\section{Konsep Produk Domestik Regional Bruto (PDRB)}

Menurut (sadono sukirno,2004) PDRB adalah merupakan nilai dari seluruh barang dan jasa yang diproduksi dalam waktu satu tahun di suatu wilayah tertentu tanpa membedakan kepemilikan faktor produksi, tapi lebih memerlukan keberadaan faktor produksi yang digunakan dalam proses produksi itu, PDRB merupakan salah satu pencerminan kemajuan ekonomi suatu daerah. Kenaikan PDRB akan menyebabkan pendapatan daerah dari sektor pajak dan retribusi meningkat. Hal tersebut berdampak pada peningkatan PAD di daerah tersebut.

Menurut (H. Saberan, 2002: 5) Produk Domestik Regional Bruto adalah nilai tambah yang mampu diciptakan berbagai aktivitas ekonomi dalam suatu wilayah. Istilah Produk Domestik Regional Bruto (PDRB) merupakan gabungan dari empat kata yaitu: Pertama; Produk, artinya seluruh nilai produksi baik barang maupun jasa, Kedua; Domestik, artinya perhitungan nilai produksi yang dihasilkan hanya oleh faktor-faktor produksi yang berada dalam wilayah domestik tanpa melihat apakah faktor produksi tersebut dikuasai oleh penduduk atau bukan, ketiga; Regional, artinya perhitungan nilai produksi yang dihasilkan hanya oleh penduduk tanpa memperhatikan apakah faktor produksi yang digunakan berada dalam wilayah domestik atau bukan, dan Keempat; Bruto, maksudnya adalah perhitungan nilai produksi kotor karena masih mengandung biaya penyusutan.

Berdasarkan pengertian istilah di atas, maka arti PDRB adalah sebagai nilai barang-barang dan jasa-jasa yang diproduksikan di dalam negara tersebut dalam satu tahun. PDRB dapat dilihat dari dua sudut pandang yaitu Pendapatan Domestik Regional Bruto dan Pengeluaran Domestik Regional Bruto

\section{Pengaruh Produk Domestik Regional Bruto Terhadap PAD}

Pertumbuhan ekonomi sebagai salah satu alat untuk mengetahui perkembangan dan struktur ekonomi suatu wilayah di nyakini masih merupakan indicator dalam menentukan arah pembangunan yang digambarkan oleh perkembangan Produk Domestic Regional Bruto(PDRB). Produk 
Domestic Regional Bruto dapat diartikan sebagai nilai barang dan jasa-jasa yang diproduksi didalam Negara tersebut dalam satu tahun tertentu. Barang-barang dan jasa-jasa ini diproduksi bukan saja oleh perusahaan milik penduduk Negara tersebut tetapi oleh penduduk Negara lain yang bertempat tinggal di Negara tersebut (sukirno,2003:33)

Semakin tinggi pendapatan seseorang maka akan semakin tinggi pula kemampuan orang untuk membayar berbagai pungutan yang ditetapkan pemerintah. Dalam konsep makro dapat dianalogikan bahwa semakin besar PDRB yang diperoleh maka akan semakin besar pula potensi penerimaan daerah. Jadi dengan adanya peningkatan PDRB maka hal ini mengindikasikan akan mendorong peningkatan pendapatan asli daerah (saragih,2003). Pendapat ini sejalan dengan Hakim Halim (2000), bahwa Pendapatan Asli Daerah di pengaruhi oleh Produk Domestik Regional Bruto.

\section{Pengeluaran Pemerintah}

Pengeluaran pemerintah adalah seluruh pembelian atau pembayaran barang dan jasa untuk kepentingan nasional, seperti pembelian persenjataan dan alat-alat kantor pemerintah, pembangunan jalan dan bendungan, gaji pegawai negeri, angkatan bersenjata, dan lainnya (Samuelson, 1997).

Pengeluaran pemerintah daerah merupakan salah satu komponen kebijakan fiskal yang bertujuan untuk laju investasi, meningkatkan kesempatan kerja, memelihara kestabilan ekonomi dan menciptakan distribusi pendapatan yang merata.

Pada tingkat daerah, pengeluaran pemerintah atau belanja daerah tercermin pada anggaran dan belanja daerah (APBD) yang memuat semua biaya yanga akan digunakan untuk menutupi semua belanja daerah dalam pelaksanaan tusas - tugas

Pengeluaran pemerintah dapat bersifat exhautive expenditure yaitu merupakan pembelian barang dan jasa dalam perekonomian yang dapat langsung dikonsumsi maupun dapat menghasilkan barang lain lagi. Di samping itu, pengeluaran pemerintah dapat pula bersifat transfer yaitu berupa pemindahan uang kepada individu - individu untuk kepentingan sosial.Jadi exhautive expenditure mengalihkan faktor - faktor produksi dari sektor swasta ke sektor pemerintah.Pengeluaran ini dapat berupa pembelian terhadap barang dan jasa yang dihasilkan oleh pemerintah sendiri, seperti jasa - jasa guru, meliter, pegawai negeri sipil, dan lain sebagainya (Suparmoko, 1987).

Menurut Dorn busch dan fischer (1987) memperlihatkan bahwa kenaikan pengeluaran pemerintah akan berpengaruh terhadap kenaikan produksi nasional yang lebih besar

Studi yang dilakukan oleh Booth (1982) yang secara langsung memperlihatkan pengaruh pengeluaran pemerintah terhadap produk dalam negeri yang pada gilirannya akan mendorong pengumutan penerimaan pajak sebagai hasil perkembangan produksi dan investasi dalam negeri

\section{Hubungan antara Pengeluaran Pemerintah dan PDRB dengan Pendapatan Asli Daerah (PAD) \\ 1. Hubungan antara Belanja Modal dengan Pertumbuhan Ekonomi}

Pembangunan sarana dan prasarana oleh pemerintah daerah berpengaruh positif pada pertumbuhan ekonomi (Kuncoro, 2004).Syarat fundamental untuk pembangunan ekonomi adalah tingkat pengadaan modal pembangunan yang seimbang dengan pertambahan penduduk. Bertambahnya infrastruktur dan perbaikannya oleh pemerintah daerah diharapkan akan memacu pertumbuhan ekonomi daerah. Secara umum pertumbuhan ekonomi dapat diartikan sebagai perkembangan kegiatan perekonomian yang menyebabkan bertambahnya produksi barang dan jasa dan kemakmuran masyarakat yang meningkat. Proses kenaikan output per kapita diproksi dengan Produk Domestik Regional Bruto per Kapita (PDRB) yang didefinisikan sebagai jumlah nilai tambah yang dihasilkan oleh 
seluruh unit usaha dalam suatu wilayah, atau merupakan jumlah seluruh nilai barang dan jasa akhir yang dihasilkan oleh seluruh unit ekonomi di suatu daerah.

2. Hubungan Antara PDRB dengan PAD

Hubungan antara PDRB dengan PAD merupakan hubungan secara fungsional, karena pajak daerah merupakan fungsi dari PDRB, yaitu dengan meningkatnya PDRB akan menambah penerimaan pemerintah dari pajak daerah. Selanjutnya dengan bertambahnya penerimaan pemerintah akan mendorong peningkatan pelayanan pemerintah kepada masyarakat yang nantinya diharapkan dapat meningkatkan produktivitas masyarakat yang akhirnya dapat meningkatkan pertumbuhan ekonomi kembali. Begitu juga sebaliknya dengan meningkatnya pertumbuhan ekonomi dan pendapatan per kapita masyarakat, maka akan mendorong kemampuan masyarakat untuk membayar pajak dan pungutan lainnya.

\section{Hubungan pengeluaran Pemerintah dengan PAD}

Menurut (Mardiasmo,2004) Optimalisasi penerimaan PAD harus didukung dengan upaya peningkatan kualitas layanan publik. Berbagai belanja yang dialokasikan pemerintah hendaknya yang manfaatnya dirasakan langsung oleh masyarakat.Hal ini berkaitan dengan retribusi.Masyarakat lebih mudah membayar retribusi daripada membayar pajak. Masyarakat tidak akan membayar apabila kualitas dan kuantitas layanan publik tidak mengalami peningkatan. Pemerintah daerah harus mampu menjalankan rumah tangganya sendiri secara mandiri.Dalam rangka meningkatkan kemandiriannya, pemerintah dituntut untuk meningkatkan pelayanan publik. Anggaran belanja daerah tidak akan logis jika pengalokasiannya cukup besar untuk belanja rutin. Belanja modal yang dilakukan pemerintah daerah diantaranya pembangunan dan perbaikan sektor pendidikan, kesehatan, transportasi, sehingga masyarakat menikmati manfaat dari pembangunan daerah.Tersedianya infrastruktur yang baik dapat mendorong terciptanya efisiensi dan efektivitas di berbagai sektor, produktivitas masyarakat diharapkan meningkat. Pemerintah perlu memfasilitasi berbagai aktivitas perekonomian, salah satunya dengan membuka kesempatan berinvestasi. Pembangunan infrastruktur dan pemberian berbagai fasilitas kemudahan dilakukan untuk meningkatkan daya tarik investasi. Dengan tersedianya fasilitas pelayanan publik membuat masyarakat akan lebih aktif dan bergairah dalam bekerja dan bertambahnya produktivitas masyarakat dan investor di daerah, akan berdampak pada peningkatan PAD.

Menurut Wong dalam Adi (2006), pembangunan infrastruktur industri mempunyai dampak yang nyata terhadap kenaikan pajak daerah.Pajak dan retribusi yang merupakan komponen PAD merupakan nilai tambah yang diperoleh dari sektor industri yang berkembang optimal.Sektor industri tersebut adalah berasal dari belanja modal. Strategi alokasi pada belanja modal akan mampu mendorong dan mempercepat pembangunan ekonomi nasional. Belanja modal diantaranya adalah belanja modal tanah, belanja modal gedung dan bangunan, belanja modal jalan dan jembatan, belanja modal alat-alat angkutan, belanja modal alat-alat berat dan belanja modal lainnya.

Desentralisasi dapat dikatakan sebagai suatu alat untuk mewujudkan tatakelola pemerintahan yang efisien dan partisipatif (Tanzi, 2002).Tujuan diterapkannya desentralisasi fiscal adalah untuk mendekatkan pemerintah dengan rakyatnya, dimana pemerintah dapat bekerja dengan lebih baik (efisien) (Rasyid,2005). Sehingga adanya instrument desentralisasi ini diharapkan dapat memberikan dampak bagi belanja pemerintah yaitu berupa peningkatan efisiensi pengeluaran sektor publik. Adanya desentralisasi fiskal ini pemerintah daerah diharapkan dapat bijak dalam melakukan peranannya untuk melakukan pengeluaran daerah 
yang seefisien mungkin dan dapat memberikan pelayanan bagi masyarakat di mulai dari pelayanan yang paling sederhana seperti dalam bidang pendidikan, kesehatan dan infrastruktur. Dalam menciptakan sumberdaya manusia yang berkualiatas yang memiliki peran yang sangat penting adalah kesehatan, pendidikan dan infrastruktur (Christiana,2012).

Besarnya komitmen pemerintah dalam membangun kualitas manusia melalui pengeluaran daerah tampakdari alokasi pengeluaran belanja daerah pada sektor pendidikan, kesehatan dan infrastruktur tersebut (Christiana,2012). Sehingga dapat dikatakan, seberapa besar pengaruh setiap dana yang dibelanjakan untuk mencapaisasaran pembangunan menjadi suatu permasalahan penting dalam alokasi pengeluaran pemerintah. Dapat dilihat dariperan pemerintah dalam rangka menciptakan pembangunan ekonomi dan kualitas hidup masyarakat pemerintahsenantiasa meningkatkanupayadenganmelakukanpe ngeluarandisektorpendidikan,kesehatan, daninfrastrukturyangselalu meningkat setiap tahunnya.

\section{STUDY EMPIRIS}

Kajian penelitian terdahulu merupakan hal yang sangat bermanfaat untuk menjadi perbandingan dan acuan yang memberikan gambaran terhadap hasilhasil penelitian terdahulu menyangkut pendapatan asli daerah. Ini disadari untuk melakukan penelitian perlu ada suatu bentuk hasil penelitian terdahulu yang dijadikan referensi pembanding dalam penelitian, untuk itu pada bagian ini akan diberikan beberapa penelitian terdahulu yang berkaitan dengan rencana penelitian ini :

Terdapat beberapa studi yang telah meneliti tentang desentralisasi diantaranya adalah Oates (1993); Utomodan Sumarsono (2009); Sasana (2006); dan Simanjuntak (2005).Studi ini fokus pada desentralisasi, pertumbuhan ekonomi, dan kesejahteraan. Menurut Simanjuntak (2005) dalam penemuannnya mengatakan bahwa danatransfer pada program desentralisasi fiskal berupa dana block grant akan memberikan pengaruh yang lebih efisien terhadap peningkatan kesejahteraan masyarakat dibandingkan dengan dana transfer berupa specific grant. Berbeda lagi dengan hasil penemuan dari Oates (1993); Utomo dan Sumarsono (2009); dan Sasana (2006) yangmengatakan bahwa desentralisasi fiskal akan mampu meningkatkan pertumbuhan ekonomi dan kesejahteraan masyarakat, karena Pemerintah Daerah akan lebih efisien dalam produksi dan penyediaan barangbarang publik.

Menurut Wahidi (2003) faktor-faktor yang mempengaruhi Pendapatan Asli Daerah di Propinsi Kalimantan timur.Penelitian ini bertujuan untuk mengetahui faktor-faktor yang mempengaruhi pendapatan asli daerah, mengetahui pengaruh pendapatan perkapita, jumlah kendaraan bermotor, jumlah tabungan dan untuk mengetahui variabel yang dominan mempengaruhi PAD Propinsi Kalimantan timur.Hasil analisis menunjukkan bahwa dari ketiga variabel bebas (pendapatan perkapita, jumlah kendaraan dan jumlah tabungan) mempunyai hubungan yang sangat erat dengan variabel terikatnya (PAD).Dari ketiga variabel bebas tersebut, variabel jumlah kendaraan roda dua maupun roda empat sangat berpengaruh terhadap PAD, hal ini dibuktikan dengan nilai t-hitung yang lebih besar dari nilai ttabel yaitu 7,098 $>2,132$ dengan koefisien korelasi sebesar 0,801.Kemudian disusul masing-masing variabel pendapatan per kapita masyarakat dan jumlah tabungan menempati urutan kedua dan ketiga.

Menurut Transna Putra Urip ( Urip Putra $T$, 2004) dalam penelitiannya pengaruh pengeluaran pemerintah dan perkembangan ekonomi terhadap PAD di provinsi Papua, menyimpulkan bahwa: pengeluaran pemerintah berpengaruh positif terhadap PAD sebesar $1.051 \%$ dan perkembangan ekonomi mempunyai pengaruh positif dan signifikan terhadap Pendapatan Asli Daerah sebesar 3,709\% Menurut H.Muhamad (Muhamad. H,2005) dalam penelitiannya tentang Faktor-faktor yang mempengaruhi pendapatan asli daerah di Samarinda, menyimpulkan bahwa: variable bebas yang terdiri dari 
PDRB, kontribusi sector pertanian, kontribusi sector pertambangan, kontribusi sector industri,kontribusi sector perdagangan dan kontribusi sector konstruksi secara bersama- sama berpengaruh terhadap PAD.

\section{Kerangka Konseptual}

Pengeluaran Pemerintah yang dilakukan pemerintah daerah diantaranya perbaikan sektor pendidikan, kesehatan, transportasi,pembangunan infrastruktur dan sarana prasarana yang ada di daerah sehingga akan berdampak pada meningkatnya pendapatan asli daerah sekaligus peningkatan pertumbuhan ekonomi daerah. di samping itu dengan tersedianya sarana prasarana yang memadai dari pemerintah daerah maka masyarakat dapat melakukan aktivitas secara aman dan nyaman dimana akan berpengaruh pada meningkatnya tingkat produktivitas. dengan adanya infrastruktur yang memadai akan menarik para investor untuk membuka lapangan usaha di segala sector PDRB sehingga akan berdampak pada meningkatnya Pendapatan Asli Daerah.

Dari penjelasan tersebut muncul suatu kerangka konsepsional yang harus dilakukan pengujian berkaitan dengan perkembangan variabel makro yaitu Pengeluaran Pemerintah sektor pendidikan dan sektor kesehatan terhadap penerimaan PAD melalui.PDRB

\section{Hipotesis}

Dalam usaha pemecahan masalah yang telah dikemukakan diatas, maka penulis membuat hipotesis Diduga Pengeluaran Pemerintah sektor pendidikan dan sektor kesehatan berpengaruh positif dan signifikan terhadap penerimaan PAD melalui.PDRBdi Kota Mataram.

\section{METODE PENELITIAN}

\section{Daerah Penelitian}

Penelitian ini dilaksanakan di Kota Mataram Propinsi Nusa Tenggara Barat. Pemilihan Kota Mataram sebagai daerah penelitian dikarenakan menjadi ibukota Propinsi NTB serta sebagai kota pendidikan dan banyak pusat layanan kesehatan yang baik.

\section{Jenis dan Sumber Data}

Jenis data yang di gunakan pada penelitian ini bersifat Kuantitatif merupakan data time series dari tahun 2005-2015. Tentang Pendapatan Asli Daerah, Pengeluaran Pemerintah sektor pendidikan dan kesehatan dan PDRB yang didapat dari Kantor Dinas Pendapatan Daerah, Badan Pusat Statistik (BPS) Kota Mataram, literaturliteratur/buku-buku dan laporan-laporan yang berkaitan dengan penulisan ini.

\section{Metode Pengumpulan Data}

Pengumpulan data yang dilakukan dalam penelitian ini dengan cara Penulis mengajukan surat izin penelitian kepada instansi-instansi yang terkait dengan penulisan ini dalam suatu wilayah penelitian, setelah diberikan izin penelitian dan mendapatkan data-data yang dibutuhkan kemudian data tersebut akan diolah dan digunakan sebagai bahan analisis untuk membuktikan hipotesa yang telah dikemukan

\section{Defenisi Operasional Variabel}

Untuk lebih mengarahkan dalam pembahasan, maka penulis memberikan batasan variabel yang meliputi :

1) Pertumbuhan Pendapatan Asli Daerah (PAD) Adalah pertumbuhan salah satu sumber pendapatan daerah yang diusahakan langsung oleh pemerintah daerah yang meliputi hasil pajak daerah, hasil retribusi daerah, hasil perusahaan milik daerah, hasil pengelolaan kekayaan daerah yang dipisahkan, dan lain-lain pendapatan asli daerah yang sah. tahun 2005-2015 yang di ukur dengan satuan \%

2) Pertumbuhan Produk Domestik Regional Bruto (PDRB) Adalah pertumbuhan nilai barang dan jasa yang dihasilkan oleh suatu daerah dalam jangka waktu tertentu, yang dihitung berdasarkan harga konstan tahun 2005-2015 dalam satuan \%

3) Pengeluaran Pemerintah sektor pendidikan Adalah anggaran yang di keluarkan pemerintah daerah untuk meningkatkan layanan publik 
dibidang pendidikan yang di ukur dengan satuan rupiah.

4) Pengeluaran Pemerintah sektor kesehatan Adalah anggaran yang di keluarkan pemerintah daerah untuk meningkatkan layanan publik dibidang kesehatan yang di ukur dengan satuan rupiah

\section{Teknik Analisis Data.}

Model analisis yang digunakan dalam penelitian ini adalah analisis jalur (Path Analisis).Model analisis jalur digunakan untuk menganalisis pola hubungan antar variabel dengan tujuan untuk mengetahui pengaruh langsung maupun tidak langsung seperangkat variabel bebas (eksogen) terhadap variabel terikat (endogen).Analisis ini menggunakan bantuan sofware AMOS 5.0.

Model analisis jalur yang digunakan dalam penelitian merujuk pada gambar 1 adalah sebagai berikut :

1. $P P D R B=\beta 1 P S P+e 1$

2. $P P D R B=\beta 2 P S K+e 1$

3. $P P A D=\beta 3 P S P+e 2$

4. $P P A D=\beta 4 P P D R B+e 2$

5. $P P A D=\beta 5 P S K+e 2$

6. $P P A D=\beta 1 P S P+\beta 4 P P D R B+e 2$

7. $P P A D=\beta 2 P S K+\beta 4 P P D R B+e 2$

Keterangan:

PPDRB = Pertumbuhan PDRB

PPAD = Pertumbuhan PAD

PSP = Pengeluaran sektor pendidikan

PSK = Pengeluaran sektor kesehatan

$\mathrm{B} 1,2,3,4,5$, = koefisien jalur

$\mathrm{E} 1,2$ = standar error

\section{Uji Normalitas.}

Suatu kumpulan data mempunyai disribusi normal jika nilai critical ratio skewness value di bawah harga mutlak 2,58. (Ghozali,2001: 110).

\section{Outlier}

Katagori outliers multivariate dalam penelitian ini jika Mahalanobis Distance yang lebih besar dari $\mathrm{X}^{2}(4$; $0,01)=13.277 \quad$ (Hair,et al dalam Ferdinand, 2002 : 102).

\section{Uji Multikolinearitas}

Nilai diterminan yang sangat kecil menunjukkan indikasi terdapatnya masalah multikolinearitas atau singularitas, (Tabachnick dan Fidell, 1998 : dalam Ferdinand, 2002 : 105)

\section{Uji Hipotesa}

Ferdinand (2002:141), analisis atau signifikansi koefisien jalur dianalisis melalui signifikansi besaran regression weights. Apabila hasil perhitungan dengan model tersebut diperoleh nilai $t$ (CR) lebih besar dari 2 atau nilai signifikansi $p \leq 0,05$, maka pengaruh antara variable satu dengan lainnya adalah signifikan.

\section{HASIL DAN PEMBAHASAN}

\section{Pengaruh Pengeluaran Pemerintah Sektor Pendidikan Terhadap Pertumbuhan PAD Dan PDRB}

Pengeluaran pemerintah sector pendidikan pengaruhnya positif dan signifikan terhadap pertumbuhan PAD dengan koefisien yang distandarisasi sebesar 1,267 Artinya, jika ada kenaikan X1 sebesar Rp 1, akan mempengaruhi pertumbuhan PAD sebesar Rp 1 x 1,267. Hal ini sesuai dengan hipotesa yang diajukan dan teori yang ada, keadaan dapat dipahami karena pengeluaran sector pendidikan yang bersifat jangka pendek seperti pelatihan ketrampilan masak memasak, elektro, mesin dan lain-lain relative cepat menimbulkan pengaruh terhadap pendirian usaha-usaha baru. Selanjutnya dari usaha-usaha baru tersebut akan membayar pajak dan retribusi sebagai tambahan PAD.

Pengeluaran pemerintah sector pendidikan (X1) terhadap pertumbuhan PDRB (Y1) memiliki pengaruh positif tetapi tidak signifikan dengan koefisien yang distandarisasi sebesar 0,567. Artinya, jika ada kenaikan X1 sebesar Rp 1, akan mempengaruhi pertumbuhan PDRB sebesar Rp 1 x 0,567.

Pengaruh variabel pengeluaran pemerintah atas pendidikan terhadap pertumbuhan ekonomi tidak signifikan.Hal tersebut tidak sesuai dengan hipotesis yang digunakan dalam penelitian, dimana pengeluaran pemerintah atas pendidikan berpengaruh terhadap pertumbuhan ekonomi.Jadi hasil penelitian tidak menunjukkan kesesuaian teori dimana pengeluaran 
pemerintah atas pendidikan seharusnya berpengaruh signifikan dan positif terhadap pertumbuhan ekonomi.

Menurut teori human capital bahwa pengeluaran pemerintah atas pendidikan dapat meningkatkan kualitas penduduk kemudian selanjutnya meningkatkan pertumbuhan ekonomi. Namun dalam penelitian ini hasilnya berkebalikan dengan teori yaitu pengeluaran pemerintah atas pendidikan dalam jangka pendek tidak berpengaruh terhadap pertumbuhan ekonomi.

Berbeda juga hasilnya dengan penelitian yang dilakukan oleh Donald $\mathrm{N}$ dan Shuanglin (1993) bahwa pengeluaran pendidikan memliki pengaruh yang positif dan signifikan terhadap pertumbuhan ekonomi.Hal ini terjadi karena pengeluaran pemerintah atas pendidikan bersifat seperti investasi yang tidak dapat langsung memberikan kontribusi terhadap pertumbuhan ekonomi.Seperti yang dikemukakan oleh Adi Widodo (2010) dalam penelitiannya bahwa pengeluaran pemerintah atas sektor public dalam hal ini pendidikan, tidak dapat berdiri sendiri sebagai variable independen. Variabel pengeluaran pemerintah harus berinteraksi dengan variabel lain.. Selain itu pengeluaran pemerintah atas pendidikan yang akan menghasilkan perbaikan di sektor pendidikan tidak dapat secara cepat mengubah kualitas angkatan kerja yang kemudian meningkatkan produktifitas kerja. Setelah itu produktifitas akan meningkat pertumbuhan ekonomi.

Hasil penelitian yang berbeda dilakukan oleh Josaphat P Kweka dan Oliver Morrisey (1999) dalam Luki Alfirman (2006) di Tanzania Hasil yang diperoleh bahwa pengeluaran pemerintah berdampak negatif terhadap pertumbuhan Dampak negative disebabkan karena tidak efisiennya pengeluaran pemerintah di Tanzania. Jurnal penelitian tersebut juga mengemukakan bahwa di negara miskin dan Negara sedang berkembang memiliki kecenderungan pengeluaran pada sektor publik seperti pendidikan bersifat konsumtif. Seharusnya menurut Todaro (2003) pengeluaran pemerintah yang ditujukan sebagai perbaikan modal manusia pada dasarnya merupakan suatu investasi.Sehingga pengeluaran tersebut tidak dapat secara langsung berpengaruh terhadap pertumbuhan ekonomi.

Hasil penelitian yang sejalan dengan hasil penelitian ini adalah penelitian yang dilakukan oleh Brata et al (2004), Todaro et al (2006), Hongyi-Li dan Huan- Liang (2013), Meylina dkk (2013), dan Monday et al (2014), bahwa pengeluaran untuk pendidikan berdampak positif terhadap pertumbuhan ekonomi.

\section{Pengaruh Pengeluaran Pemerintah Sektor Kesehatan Terhadap Pertumbuhan PAD Dan PDRB}

Pengeluaran pemerintah sector kesehatan pengaruhnya negatif dan tidak signifikan terhadap pertumbuhan PAD dengan koefisien yang distandarisasi sebesar -1,288. Artinya, jika ada kenaikan X1 sebesar Rp 1, akan mempengaruhi secara negative pertumbuhan PAD sebesar Rp $1 \mathrm{x}$ 1,288. Hal ini tidak sesuai dengan hipotesa yang diajukan dan teori yang ada, keadaan dapat dipahami karena pengeluaran sector kesehatan yang bersifat jangka panjang seperti pendidikan keperawatan dan tenaga kesehatan yang lainnya relative lama menimbulkan pengaruh terhadap pendirian usaha-usaha baru di bidang kesehatan.

Pengeluaran pemerintah sector kesehatan (X2) terhadap pertumbuhan PDRB (Y1) memiliki pengaruh negatif tetapi tidak signifikan dengan koefisien yang distandarisasi sebesar $-0,654$. Artinya, jika ada kenaikan X1 sebesar Rp 1, akan mempengaruhi penurunan pertumbuhan PDRB sebesar $\operatorname{Rp} 1 \mathrm{x}$ 0,654 .

Variabel pengeluaran pemerintah atas kesehatan dalam jangka pendek memiliki arah hubungan negatif terhadap pertumbuhan ekonomi dan tidak signifikan, hasil yang diperoleh tidak sesuai dengan hipotesis yang digunakan dalam penelitian ini.Seharusnya menurut teori hubungan pengeluaran pemerintah atas kesehatan di negara sedang berkembang seperti Indonesia sedang mengalami tahap perkembangan 
menengah, dimana pemerintah harus menyediakan lebih banyak sarana publik seperti kesehatan untuk meningkatkan produktifitas ekonomi.Sarana kesehatan dan jaminan kesehatan harus dirancang sedemikian rupa oleh pemerintah melalui pengeluaran pemeritah. Dalam jangka pendek pengeluaran pemerintah atas kesehatan memang belum dapat mempengaruhi pertumbuhan ekonomi, karena proses perbaikan kesehatan masyarakat melalui pengeluaran pemerintah tersebut tidak dapat langsung terlihat pengaruhnya, terdapat tenggang waktu ketika pemerintah mengeluarakan sejumlah anggaran pembangunan untuk kesehatan hingga kualitas kesehatan masyarakat meningkat dan pada akhirnya berkontribusi pada peningkatan pertumbuhan ekonomi. Sebagaimana hasil penelitian yang dilakukan oleh Barro 1996 yang menyimpulkan bahwa status kesehatan, yang diukur dengan harapan hidup, merupakan kontributor penting untuk pertumbuhan ekonomi.Bahkan, kesehatan, menurut Barro 1996, adalah prediktor yang lebih awal dari pendidikan terhadap pertumbuhan ekonomi. David (2009), .mengemukakan bahwa kondisi kesehatan cenderung memainkan peran kausal dalam proses pertumbuhan dalam ekonomi. Dalam jangka panjang, variabel pengeluaran pemerintah atas kesehatan memiliki arah hubungan yang positif. Namun, hasil penelitian menunjukkan bahwa variabel pengeluaran pemerintah atas kesehatan tidak berpengaruh secaranya nyata terhadap pertumbuhan ekonomi.

Hasil penelitian yang menunjukkan tidak adanya pengaruh variabel pengeluaran pemerintah atas kesehatan dapat juga berarti rendahnya keefektifan anggaran pemerintah dalam realisasinya..Hasil temuan pada penelitian ini sejalan dengan penelitian yang dilakukan oleh Donald N dan Shuanglin (1993) pada 58 negara Asia dan Afrika. Pengeluaran pemerintah atas kesejahteraan atau dalam kaitannya dengan kesehatan berpengaruh negatif dan tidak signifikan terhadap pertumbuhan ekonomi. Penjelasan dalam penelitian tersebut menyebutkan untuk negara miskin dan sedang berkembang sifat pengeluaran pemerintah atas sektor publik bersifat konsumsi bukan investasi sehingga dalam jangka panjang pengeluaran pemerintah atas kesehatan tidak berpengaruh terhadap pertumbuhan ekonomi.Variabel pengeluaran pemerintah atas kesehatan dalam jangka panjang dan jangka pendek tidak dapat langsung mempengaruhi pertumbuhan ekonomi.

\section{Pengaruh Pertumbuhan PDRB Terhadap Pertumbuhan PAD}

Berdasarkan hasil uji hipotesis pada table 4.8 dan 4.9 menunjukkan bahwa pertumbuhan PDRB (Y1) memiliki pengaruh negatif terhadap pertumbuhan PAD tetapi tidak signifikan dengan koefisien yang distandarisasi sebesar -0,317. Artinya, jika ada kenaikan Y1 sebesar Rp 1, akan mempengaruhi penurunan pertumbuhan PAD sebesar Rp $1 \mathrm{x}$ 0,317 . Hal ini tidak sesuai dengan hipotesis yang diajukan dalam penelitian ini dan teori yang ada.

Hasil penelitian ini bertolak belakang dengan penelitiannya Transna Putra Urip ( Urip Putra T, 2004) dalam penelitiannya menyimpulkan bahwa: pengeluaran pemerintah berpengaruh positif terhadap PAD dan perkembangan ekonomi mempunyai pengaruh positif dan signifikan terhadap Pendapatan Asli Daerah. Keadaan ini dapat dijelaskan bahwa di Kota Mataram banyak berkembang kegiatan-kegiatan ekonomi seperti perhotelan, penginapan, restoran, kerajinan emas dan mutiara, travel dan lain-lainnya sebagai pendukung industry pariwisata, namun kegiatan tersebut jika dikaitkan dengan perolehan PAD belum maksimal. Hal ini disebabkan pengelolaan potensipotensi PAD masih harus ditingkatkan.

\section{Pengaruh Pengeluaran Pemerintah Sektor Pendidikan Dan Kesehatan Terhadap Pertumbuhan PAD Secara Tidak Langsung Melalui Pertumbuhan PDRB}

Berdasarkan hasil uji hipotesis pada table 4.10 menunjukkan bahwa pengeluaran pemerintah sector 
pendidikan (X1) terhadap pertumbuhan PAD secara tidak langsung melalui pertumbuhan PDRB memiliki pengaruh negatif dan tidak signifikan dengan koefisien yang distandarisasi sebesar 0,180 . Artinya, jika ada kenaikan $\mathrm{X} 1$ sebesar Rp 1, akan mempengaruhi penurunan pertumbuhan PAD sebesar Rp 1 x $-0,180$. Sebaliknya untuk pengeluaran pemerintah sector kesehatan (X2) terhadap pertumbuhan PAD secara tidak langsung melalui pertumbuhan PDRB memiliki pengaruh positif dan tidak signifikan dengan koefisien yang distandarisasi sebesar 0,207 . Artinya, jika ada kenaikan X1 sebesar $\mathrm{Rp} 1$, akan mempengaruhi kenaikan pertumbuhan PAD sebesar Rp 1 x 0,207. Hal ini tidak sesuai dengan hipotesis yang diajukan dalam penelitian ini dan teori yang ada.

Menurut (Mardiasmo,2004) Optimalisasi penerimaan PAD harus didukung dengan upaya peningkatan kualitas layanan publik. Berbagai belanja yang dialokasikan pemerintah hendaknya yang manfaatnya dirasakan langsung oleh masyarakat. Hal ini berkaitan dengan retribusi. Anggaran belanja daerah tidak akan logis jika pengalokasiannya cukup besar untuk belanja rutin. Belanja modal yang dilakukan pemerintah daerah diantaranya pembangunan dan perbaikan sektor pendidikan, kesehatan, transportasi, sehingga masyarakat menikmati manfaat dari pembangunan daerah. Dengan tersedianya fasilitas pelayanan publik membuat masyarakat akan lebih aktif dan bergairah dalam bekerja dan bertambahnya produktivitas masyarakat dan investor di daerah, akan berdampak pada peningkatan PAD.

\section{KESIMPULAN DAN SARAN}

\section{Kesimpulan}

Berdasarkan hasil pembahasan yang telah diuraikan pada bagian sebelumnya, maka dapat diambilbeberapa kesimpulan sebagai berikut:

1. Pengeluaran pemerintah sektor pendidikan pengaruhnya positif dan signifikan terhadap pertumbuhan PAD
2. Pengeluaran pemerintah sektor pendidikan (X1) terhadap pertumbuhan PDRB (Y1) memiliki pengaruh positif tetapi tidak signifikan

3. Pengeluaran pemerintah sektor kesehatan pengaruhnya negatif dan tidak signifikan terhadap pertumbuhan PAD

4. Pengeluaran pemerintah sektor kesehatan (X2) terhadap pertumbuhan PDRB (Y1) memiliki pengaruh negatif tetapi tidak signifikan

5. Pertumbuhan PDRB (Y1) memiliki pengaruh negatif terhadap pertumbuhan PAD tetapi tidak signifikan

6. Pengeluaran pemerintah sektor pendidikan (X1) terhadap pertumbuhan PAD secara tidak langsung melalui pertumbuhan PDRB memiliki pengaruh negatif dan tidak signifikan

7. Pengeluaran pemerintah sektor kesehatan (X2) terhadap pertumbuhan PAD secara tidak langsung melalui pertumbuhan PDRB memiliki pengaruh positif dan tidak signifikan

Saran

1. Variabel-variabel pada penelitian ini tidak dapat langsung mempengaruhi pertumbuhan ekonomi maka disarankan untuk melakukan peningkatan proporsi pengeluaran pemerintah atas pendidikan dan kesehatan yang masih rendah menyebabkan kelambanan pengaruhnya terhadap pertumbuhan ekonomi

2. Variabel penelitian pengeluaran pemerintah atas pendidikan dan kesehatan sebagai indicator dari Indek Pembangunan Manusia (IPM), maka pada penelitian berikutnya perlu ditambahkan variable IPM. 


\section{DAFTAR PUSTAKA}

Adi dalam wong,2006." pembangunan infrastruktur". Bandung

Atep Adya Barata." Pendapatan asli daerah ." terjemahkan Barata, jakarta 2004

Azis,1997. "Pendapatan Asli Daerah".Jakarta: Erlangga

Brata.2004."Pengaruh Pendapatan Asli Daerah Terhadap Pertumbuhan Ekonomi". Jakarta

Brata, Aloysius Gunadi. (2004). Analisis Hubungan Imbal Balik Antara Pembangunan Manusia dan Kinerja Ekonomi Daerah Tingkat II di Indonesia. Yogyakarta: Lembaga Penelitian - Universitas Atma Jaya.

Baum, Donald N and Shuanglin Lin. 1993..The Differential Effects on Economic Growth of Government Expenditure on Education, Welfare, and Defense.Journal of Economic Development, Vol 18 No.1 h.175-185

Daru Kuncoro, 2003. Analisis Kemampuan PAD Kabupaten/Kota di Propinsi Jawa Tengah, Tesis Pasca Sarjana UNDIP, Tidak diterbitkan

David, Ben Nissim. (2009). Economic Growth and its Effect on Public Health.International Journal of Social Economics.Vol. 36 No. 3.Hal.252-273.

Ferdinand. A, 2002, Structural Equation Modelling dalam Penelitian Manajemen, Badan Penerbit, Universitas Diponegoro, Semarang.

Geodhart, C, "Garis-Garis Besar Keuangan Negara", Terjemahan Ratmoko, Jakarta, Jambatan, 1982

Hongyi-Li \& Huang-Liang.(2010). Health, Education and Economic Growth in East Asia.Journal of Chinese Economic and Foreign Trade Studies Vol. 3 No. 2, 2010 pp. 110-131.Emerald Group Publishing Limited 1754-4408DOI.

Kuncoro,1995 : 334-358." Otonomi daerah". Jakarta: Fokusmedia

Mardiasmo, 2004."Optimalisasi Belanja modal". Jakarta: Erlangga

Meylina, dkk.(2013). Pengaruh Pengeluaran Pemerintah Daerah pada sektor Pendidikan dan Kesehatan terhadap Indeks Pembangunan Manusia Di Indonesia.Jurnal Pendidikan Ekonomi dan Bisnis, Vol.1.No.1. 2013.

Monday, Robinson O. Et al. (2014).Government Expenditures and Economic Growth: The Nigerian Experience. Mediterranean Journal of Social Sciences MCSER Publishing, Rome-Italy Vol 5 No 10 June 2014.

Oates, W. 1993.Fiscal Decentralization and Economic Development.National Tax Journal $X L V I, 237-243$.

Saberan.H, 2002:5."Produk Domestik Regional Bruto". Jakarta: Rajawali

Sasana, Hadi. 2009. Peran Desentralisasi Fiskal terhadap Kinerja Ekonomi di Kabupaten/Kota Propinsi Jawa Tengah. Jurnal Ekonomi Pembangunan, Vol. 10, No. 1,103-124. 
14 | Hadi Mahmudi,A6dul Manan,Mustain/Analisis Pengaruh Pengeluaran ...

Simanjuntak,RobertA.2005. Hubungan Keuangan Pusat dan Daerah dalam Pasang Surut Otonomi Daerah: Sketsa Perjalanan 100 Tahun, Editor: Anhar Ganggang, Yayasan Tifa,Jakarta.

Sukirno,1978."pertumbuhan ekonomi".Jakarta, Lembaga Penerbit Fakultas Ekonomi Universitas Indonesia, 1985

Suparmoko,1987."Pengeluaran Pemerintah". Lembaga Penerbit Fakultas Ekonomi Universitas Erlangga

Undang-undang No.32 tahun 2004, “Undang-undang Otonomi Daerah”, Jakarta, Foku s media, 2004

Uppal, 1986."keuangan pusat dan daerah". Jakarta: erlangga

Wahidi,."faktor-faktor yang mempengaruhi Pendapatan Asli Daerah Propinsi Kalimantan timur" KAL-TIM, 2003 